\title{
Nitrogen Fixation Aligns with nifH Abundance and Expression in Two Coral Trophic Functional Groups
}

\section{OPEN ACCESS}

Edited by:

Ute Hentschel Humeida,

GEOMAR Helmholtz Centre for Ocean

Research Kiel (HZ), Germany

Reviewed by:

Julie L. Meyer,

University of Florida, United States

Raquel Peixoto,

Federal University of Rio de Janeiro,

Brazil

*Correspondence:

Christian Wild

christian.wild@uni-bremen.de

Christian R. Voolstra

christian.voolstra@kaust.edu.sa

tThese authors have contributed equally to this work.

Specialty section:

This article was submitted to

Microbial Symbioses,

a section of the journa

Frontiers in Microbiology

Received: 28 April 2017 Accepted: 12 June 2017

Published: 28 June 2017

Citation:

Pogoreutz C, Rädecker N, Cárdenas A, Gärdes A, Wild C and Voolstra CR (2017) Nitrogen Fixation

Aligns with nifH Abundance and Expression in Two Coral Trophic

Functional Groups.

Front. Microbiol. 8:1187.

doi: 10.3389/fmicb.2017.01187

\author{
Claudia Pogoreutz ${ }^{1,2,3 \dagger}$, Nils Rädecker ${ }^{1,2+}$, Anny Cárdenas ${ }^{1,4}$, Astrid Gärdes ${ }^{4}$, \\ Christian Wild ${ }^{2 *}$ and Christian R. Voolstra ${ }^{1 *}$
}

'Red Sea Research Center, Division of Biological and Environmental Science and Engineering (BESE), King Abdullah University of Science and Technology (KAUST), Thuwal, Saudi Arabia, ${ }^{2}$ Marine Ecology and Coral Reef Ecology Group, Faculty of Biology and Chemistry, University of Bremen, Bremen, Germany, ${ }^{3}$ Department of Ecology, Leibniz Center for Tropical Marine Research, Bremen, Germany, ${ }^{4}$ Tropical Marine Microbiology Group, Department of Biogeochemistry and Geology, Leibniz Center for Tropical Marine Research, Bremen, Germany

Microbial nitrogen fixation (diazotrophy) is a functional trait widely associated with tropical reef-building (scleractinian) corals. While the integral role of nitrogen fixation in coral nutrient dynamics is recognized, its ecological significance across different coral functional groups remains yet to be evaluated. Here we set out to compare molecular and physiological patterns of diazotrophy (i.e., nifH gene abundance and expression as well as nitrogen fixation rates) in two coral families with contrasting trophic strategies: highly heterotrophic, free-living members of the family Fungiidae (Pleuractis granulosa, Ctenactis echinata), and mostly autotrophic coral holobionts with low heterotrophic capacity (Pocilloporidae: Pocillopora verrucosa, Stylophora pistillata). The Fungiidae exhibited low diazotroph abundance (based on nifH gene copy numbers) and activity (based on nifH gene expression and the absence of detectable nitrogen fixation rates). In contrast, the mostly autotrophic Pocilloporidae exhibited nifH gene copy numbers and gene expression two orders of magnitude higher than in the Fungiidae, which coincided with detectable nitrogen fixation activity. Based on these data, we suggest that nitrogen fixation compensates for the low heterotrophic nitrogen uptake in autotrophic corals. Consequently, the ecological importance of diazotrophy in coral holobionts may be determined by the trophic functional group of the host.

Keywords: coral reefs, metaorganism, symbiosis, nitrogen cycling, heterotrophy, autotrophy, diazotrophy, bacteria

\section{INTRODUCTION}

Tropical reef-building (scleractinian) corals are holobionts consisting of the coral animal host, dinoflagellate algae of the genus Symbiodinium, and a diverse assemblage of other microbes (Rohwer et al., 2002). These microbes form host-specific associations and provide key functional traits within the coral holobiont. Among these traits, biological nitrogen fixation is considered to be of high ecological significance, as nitrogen fixing Bacteria and Archaea, the diazotrophs, are widely associated with corals (Lema et al., 2012, 2014). Indeed, coral-associated nitrogen fixation provides an important source of nitrogen for Symbiodinium (Lesser et al., 2007; Benavides et al., 2016; Pogoreutz et al., 2017), thereby helping to sustain holobiont productivity when nutrients are scarce (Cardini et al., 2015). 
While nitrogen fixation rates in scleractinian corals exhibit species-specific variation (Shashar et al., 1994; Cardini et al., 2015), the molecular and ecological drivers of these patterns remain unexplored. Scleractinian coral holobionts are mixotrophic, i.e., can draw energy and nutrients from both autotrophic and heterotrophic sources. Importantly, coral holobionts range from being mostly heterotrophic to mostly autotrophic (Rahav et al., 1989; Muscatine, 1990). As nitrogen fixation is a highly energy-consuming functional trait (Mortenson, 1964), its contribution (and thereby relevance) to holobiont metabolism may differ among trophic functional groups of corals. In this study, we therefore set out to compare rates of nitrogen fixation with coral-associated diazotroph abundance and activity in a comparative coral taxonomic framework assaying highly heterotrophic (Pleuractis granulosa, Ctenactis echinata) and mostly autotrophic (Pocillopora verrucosa, Stylophora pistillata) corals (Muscatine et al., 1984; Muscatine and Kaplan, 1994; Houlbrèque and Ferrier-Pagès, 2009; Ziegler et al., 2014). To do this, we indirectly quantified coral holobiont-associated microbial nitrogen fixation activity from acetylene reduction assays (ARA) (Rädecker et al., 2014). In addition, we assessed coral tissue-associated relative gene copy numbers and expression of the nifH gene, a common biomarker for diazotrophs (Gaby and Buckley, 2012) using quantitative PCR ( $\mathrm{qPCR}$ ) to investigate relative diazotroph community sizes along with their activity.

\section{MATERIALS AND METHODS}

\section{Collection and Maintenance of Corals}

Four species of coral, i.e., two species of Fungiidae (P. granulosa, C. echinata) and Pocilloporidae ( $P$. verrucosa, S. pistillata) were collected at the wave-exposed site of the inshore reef Fsar $\left(22^{\circ}\right.$ $13.974 \mathrm{~N}, 39^{\circ} 01.760 \mathrm{E}$ ) off the Saudi Arabian coastline in the Central Red Sea during February 2016. The Saudi Coastguard Authority under the auspices of KAUST University issued sailing permits to the collection site, which included sampling of coral specimens. The above coral families species were selected due to their distinct trophic ecologies (Alamaru et al., 2009; Hoeksema and Waheed, 2012; Ziegler et al., 2014) and their previous use in physiological and molecular studies (Muscatine and Kaplan, 1994; Bayer et al., 2013; Baria et al., 2015; Roder et al., 2015; Sawall et al., 2015; Röthig et al., 2016; Pogoreutz et al., 2017).

Five replicate samples were collected for each coral species for nitrogen fixation measurements and three replicate samples for RNA/DNA extractions, respectively (i.e., [5 +3$]$ replicate samples $\times 4$ species $=32$ samples). We collected individuals of equal size for Fungiidae and colony fragments for Pocilloporidae. For nucleic acid extraction, all samples were flash-frozen in liquid nitrogen immediately after collection and stored at $-80^{\circ} \mathrm{C}$ until further processing. Coral samples for nitrogen fixation measurements were transferred to the wet lab facility of the Coastal and Marine Resources (CMOR) Core Lab at the King Abdullah University of Science and Technology (KAUST). Corals were acclimated for 4 weeks prior to the start of the experiment in separate flow-through aquarium tanks and continuously supplied with sediment-filtered seawater from inshore reefs located $1.5 \mathrm{~km}$ off KAUST to achieve constant maintenance conditions $(150 \mathrm{~L}$ aquaria, seawater turnover rate $300 \mathrm{~L} \mathrm{~h}^{-1}$, temperature at $\sim 28^{\circ} \mathrm{C}$; salinity at 40; dissolved oxygen $>6.0 \mathrm{mg} \mathrm{O} \mathrm{O}^{-1}$, dissolved inorganic nitrogen $\leq 0.6 \mu \mathrm{Mol}^{-1}$, and phosphorus $\leq 0.3 \mu \mathrm{Mol}$ $\mathrm{l}^{-1}$ at all times; photon flux of $\sim 150 \mu \mathrm{mol} \mathrm{m}^{-2} \mathrm{~s}^{-1}$ on a $12: 12 \mathrm{~h}$ light/dark cycle).

\section{Nitrogen Fixation Measurements}

Nitrogen fixation rates were calculated indirectly from ethylene $\left(\mathrm{C}_{2} \mathrm{H}_{4}\right)$ evolution via ARA incubations as described previously (Rädecker et al., 2014; Pogoreutz et al., 2017). Incubations were conducted in gas-tight $1 \mathrm{~L}$ glass chambers in $800 \mathrm{ml}$ of seawater and $200 \mathrm{ml}$ of $20 \%$ acetylene-enriched air headspace (Figure 1). Each jar contained a single coral sample (i.e., individual polyp or colony fragment, see above). Five coral samples per species were incubated in seawater. Two additional chambers filled exclusively with seawater (i.e., without coral samples) served as controls to correct for planktonic background metabolism. During the $24 \mathrm{~h}$ incubations, chambers were submersed in a tempered water bath and constantly stirred $(600 \mathrm{rpm})$ to ensure stable measurement conditions $\left(28^{\circ} \mathrm{C}, 12: 12 \mathrm{~h}\right.$ light/dark cycle, photon flux of $\left.\sim 150 \mathrm{~mol} \mu \mathrm{mol} \mathrm{m} \mathrm{m}^{-2} \mathrm{~s}^{-1}\right)$. Gas samples were collected after 0 and 24 h of incubation. $\mathrm{C}_{2} \mathrm{H}_{4}$ concentrations in gas samples were quantified by gas chromatography and flame

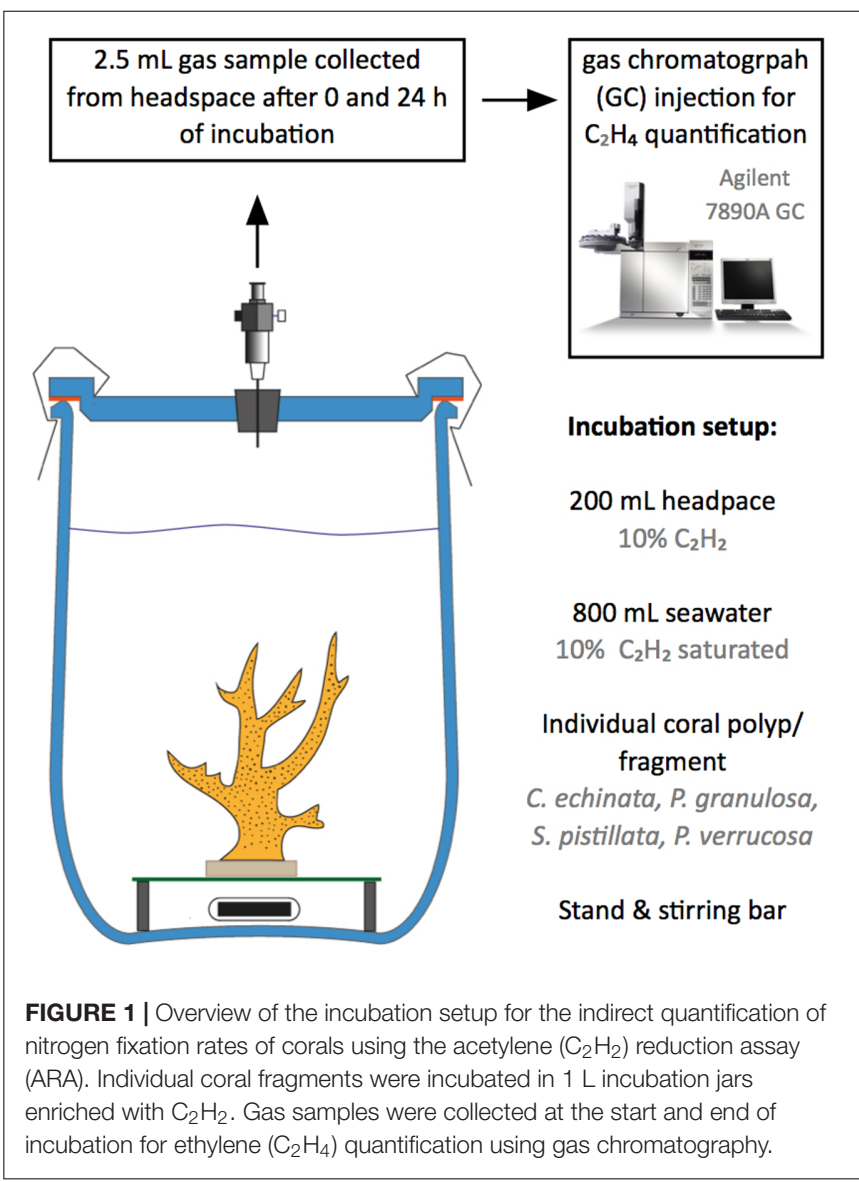


ionization detection (Agilent 7890A GC system with Agilent HP-AL/S column (Agilent technologies, United States); lower detection limit for $\left.\mathrm{C}_{2} \mathrm{H}_{4}=1 \mathrm{ppm}\right)$. Ethylene concentrations were normalized to coral surface areas, which were based on $3 \mathrm{D}$ models of the coral skeleton generated with the software Remake v117.25.67 (Autodesk Inc., United States). As we acknowledge the ongoing discussion regarding the appropriate conversion factor, nitrogen fixation is presented as $\mathrm{C}_{2} \mathrm{H}_{4}$ evolution rates (mean $\pm \mathrm{SE}$ ) without conversion into actual nitrogen fixation rates (Hardy et al., 1968; Wilson et al., 2012).

\section{Nucleic Acid Isolation and qPCR}

Tissue-associated relative gene copy numbers and expression of the nifH gene were quantified for each coral species using a qPCR assay. For this purpose, RNA and DNA were extracted from all corals using the Qiagen AllPrep DNA/RNA Mini Kit (Qiagen, Germany) according to manufacturer's instructions. Coral tissue was air-blasted off the skeleton on ice with RLT Plus buffer and using airflow from a sterile air gun. For P. granulosa and $C$. echinata, tissue was blasted off from both oral (top) and aboral (bottom) surfaces and pooled subsequently. A total of $600 \mu \mathrm{l}$ tissue slurry per sample were used for RNA and DNA extractions. DNA extractions were quantified and quality checked using a NanoDrop 2000c (Thermo Scientific, United States) and adjusted to a concentration of $10 \mathrm{ng} \mu \mathrm{L}^{-1}$. For cDNA synthesis, the SuperScript III First Strand Synthesis SuperMix kit (Thermo Scientific, United States) was used according to manufacturer's instructions using $500 \mathrm{ng}$ of total RNA input in $20 \mu \mathrm{L}$ reactions.

The qPCRs were run in triplicates for gDNA (to quantify gene copy number) and cDNA (to quantify gene expression) with the Platinum SYBR Green qPCR SuperMix kit (Invitrogen, Carlsbad, CA, United States) using $5 \mu \mathrm{L}$ SuperMix, $0.2 \mu \mathrm{L}$ ROX reference dye, $0.2 \mu \mathrm{L}$ of each $10 \mu \mathrm{M}$ primer, $1 \mu \mathrm{L}$ of cDNA, and RNAse-free water to adjust the reaction volume to $10 \mu \mathrm{l}$. Determination of relative gene copy numbers (from DNA) and mRNA expression of the nifH gene in coral tissue was determined by normalization against the ITS2 of Symbiodinium (Arif et al., 2014). This multi copy gene marker is exceptionally well-suited for this purpose given its high abundance, stable expression, and the circumstance that Symbiodinium show a constant cellspecific density in the majority of coral species (Muscatine et al., 1998). Of note, Symbiodinium are the most important sink for fixed nitrogen in the coral holobiont (Falkowski et al., 1993; Lesser et al., 2007; Cardini et al., 2015; Aranda et al., 2016; Pogoreutz et al., 2017). For the amplification of nifH, the primers F2 5'-TGYGAYCCIAAIGCIGA-3' and R6 5'-TCIGGIGARATGATGGC-3' were used (Gaby and Buckley, 2012). To amplify the Symbiodinium ITS2 region, the primers ITSintfor2 5'-GAATTGCAGAACTCCGTG-3' and ITS2-reverse 5'-GGGATCCATATGCTTAAGTTCAGCGGGT-3' were used (LaJeunesse, 2002). All amplicons were amplified in the same qPCR run using the following thermal profile: $2 \mathrm{~min}$ at $50^{\circ} \mathrm{C}$, $1 \mathrm{~min}$ at $94^{\circ} \mathrm{C}$, followed by 50 cycles of $94^{\circ} \mathrm{C}$ for $30 \mathrm{~s}, 51^{\circ} \mathrm{C}$ for $1 \mathrm{~min}, 72^{\circ} \mathrm{C}$ for $1 \mathrm{~min}$, and an extension cycle of $1 \mathrm{~min}$ at $72^{\circ} \mathrm{C}$. Specificity of amplification was confirmed by melting curve analysis. Standard calibration curves were run simultaneously covering 6 orders of magnitude $\left(10^{4}-10^{9}\right.$ copies of template per assay). Relative fold change of copies of the nifH gene was calculated as $2^{(-\Delta \Delta \mathrm{Ct})}$ against ITS2 gene copy numbers using $P$. granulosa samples as the reference.

\section{Statistical Analysis}

All statistical analyses were run in SigmaPlot 13 (Systat Software $\mathrm{GmbH}$, Germany). A student's $t$-test was run to assess species level differences on nitrogen fixation rates. To assess family leveldifferences in nifH gene copy numbers and expression, a one-way ANOVA was conducted with subsequent post hoc Bonferroni Correction. To test for a significant relationship between nifH gene copy number and expression within each of the two coral families, a non-linear regression was conducted with relative gene copy numbers as the predictor and relative gene expression as the dependent variable.

\section{RESULTS}

Both species of the mostly autotrophic Pocilloporidae (P. verrucosa, S. pistillata) exhibited detectable gross (i.e., holobiont $)$ nitrogen fixation $(0.03 \pm 0.04$ and $0.01 \pm 0.00 \mathrm{nmol}$ $\mathrm{C}_{2} \mathrm{H}_{4}$ day $^{-1} \mathrm{~cm}^{-2}$, respectively) (Figures $2 \mathrm{~A}, \mathbf{B}$ ). In contrast, nitrogen fixation remained below the detection limit for both species ( $P$. granulosa, C. echinata) of the highly heterotrophic Fungiidae (Figures 2A,B). This pattern of differential nitrogen fixation activity between the two coral families aligned with nifH abundance and expression. Corals in the Pocilloporidae family showed a significantly higher abundance of nitrogenfixing bacteria (assessed via relative nifH gene copy number) compared to both members of the Fungiidae family (ANOVA, $F=40.61, p<0.001$; Figure 3A and Supplementary Table S1). A similar pattern was confirmed for diazotroph activity, with the Pocilloporidae having higher relative nifH gene expression than the two fungiid species (ANOVA, $F=12.30$, $p<0.001$; Figure 3B and Supplementary Table S1). Specifically, $P$. verrucosa and S. pistillata showed 23- and 431-fold higher relative diazotroph abundance and 95- to 480-fold higher relative gene expression compared to $P$. granulosa, respectively (Supplementary Table S1). Non-linear regression revealed a strong significant relationship between nifH copy numbers and expression in the two species of Pocilloporidae $\left(R^{2}=71.49\right.$, $p=0.0339)$, but only a weak although significant relationship in the two Fungiidae $\left(R^{2}=0.07, p=0.0288\right)$.

\section{DISCUSSION}

The present study investigated physiological and molecular patterns of nitrogen fixation along with diazotroph abundance in corals representing two different trophic functional groups (autotrophy vs. heterotrophy). This was achieved by assessing nitrogen fixation activity (as assessed via ARA) as well as tissueassociated relative gene copy numbers and expression of the nifH gene (as assessed via qPCR) in a comparative species framework. The investigated corals exhibited similar patterns within functional groups, but marked differences between functional groups for all measurements. 


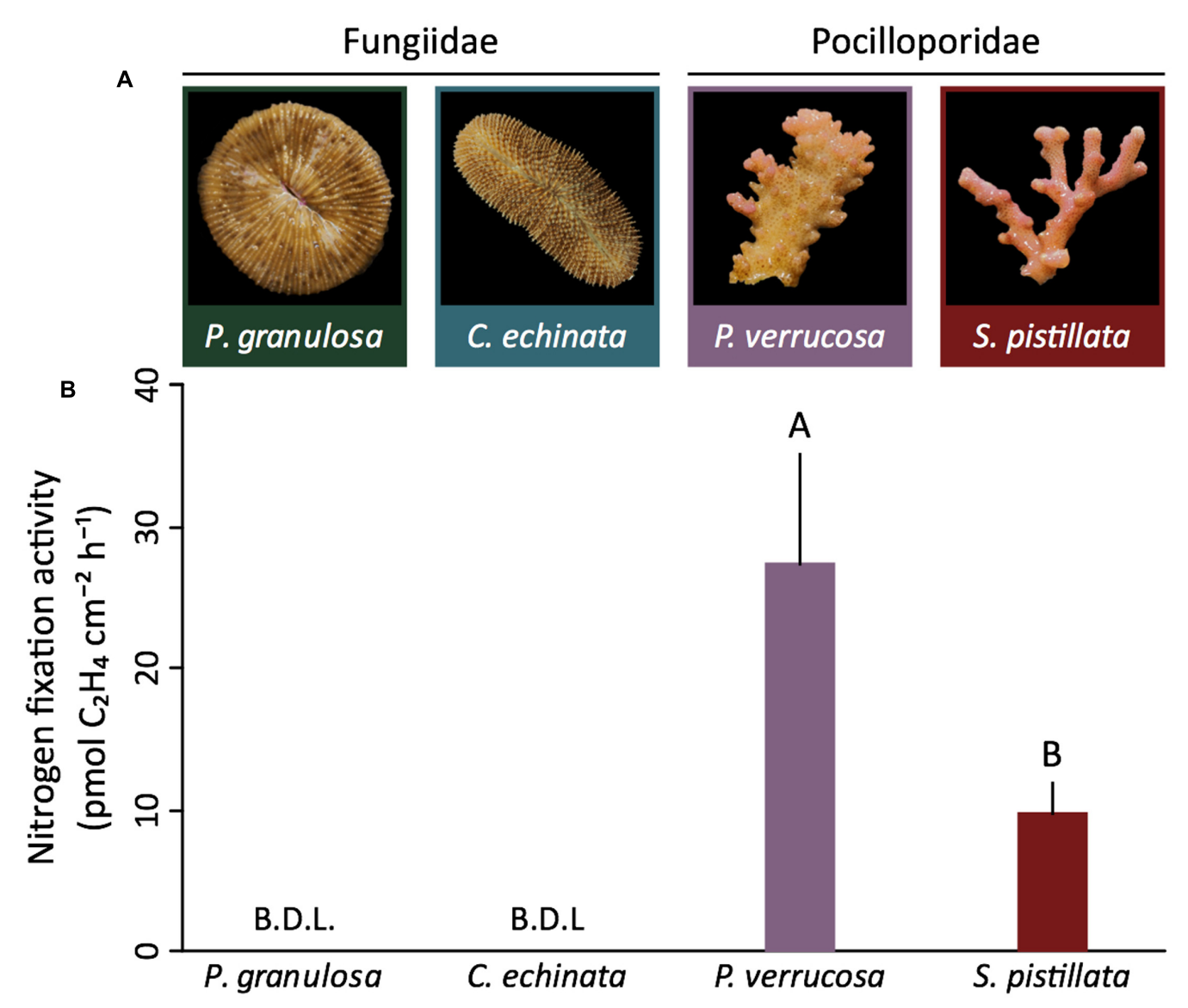

FIGURE 2 | Microbial nitrogen fixation rates in four tropical scleractinian corals from two different trophic functional groups. (A) Representative specimens of the investigated coral species from the highly heterotrophic Fungiidae and the mostly autotrophic Pocilloporidae. (B) Coral-associated nitrogen fixation rates $(n=5$ per species) as assessed indirectly from acetylene reduction assays. Nitrogen fixation rates of the pocilloporids $P$. verrucosa and $S$. pistillata are significantly different from each other ( $t$-test, $t=3.17, p=0.01$ ). In contrast, nitrogen fixation remained below the detection limit (B.D.L.) in both Fungiidae. Nitrogen fixation rates are averaged over $24 \mathrm{~h}$ (i.e., include light and dark fixation) and presented as mean \pm SE. Different letters above bars indicate significant differences between groups ( $p<0.05)$.
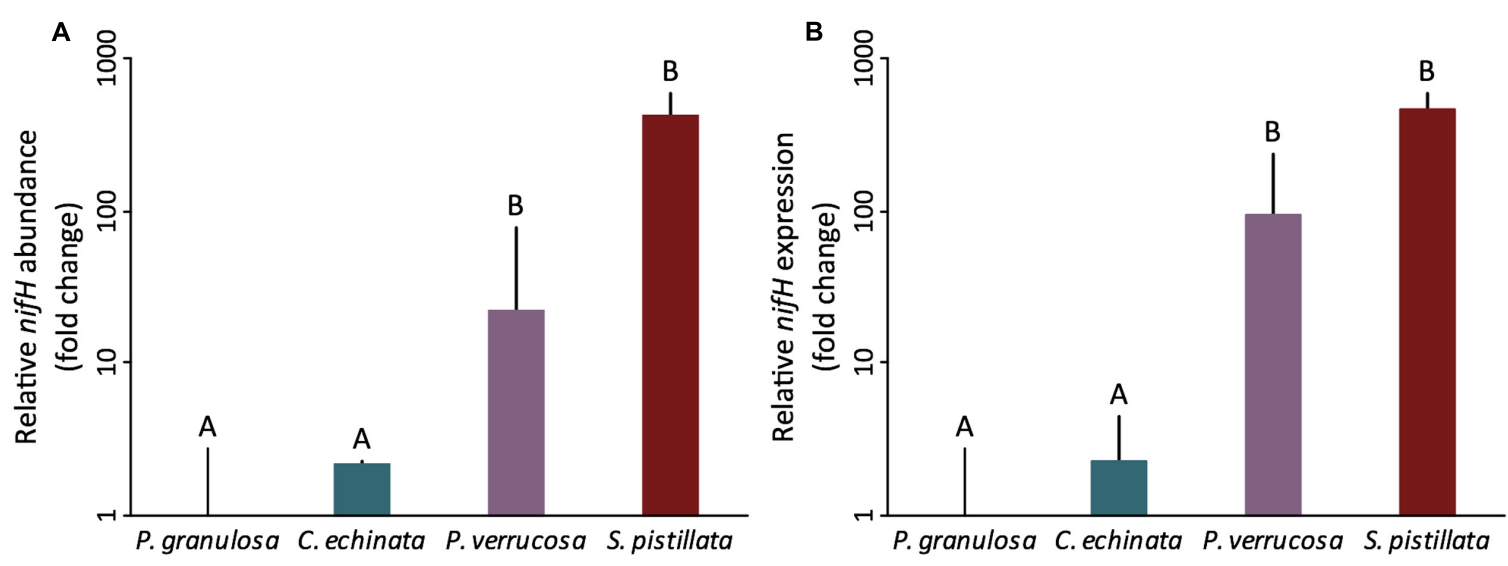

FIGURE 3 | Diazotroph abundance (A) and activity (B) in four tropical scleractinian corals ( $n=3$ per species) from two different trophic functional groups (the highly heterotrophic Fungiidae and the mostly autotrophic Pocilloporidae) as measured by coral-tissue associated nifH relative gene copy numbers and expression referenced against the Internal Transcriber Space 2 (ITS2) of Symbiodinium via qPCR. Significant family-level differences are apparent for relative nifH gene copy numbers and gene expression (ANOVA, $F=40.61 p<0.001$ and ANOVA, $F=12.30, p<0.001$, respectively). Data are shown as mean fold changes in relation to $P$. granulosa; error bars indicate upper confidence interval. Different letters above bars indicate significant differences between groups $(p<0.05)$. 
Our data are within the range of nitrogen fixation rates published for pocilloporid corals (Shashar et al., 1994; Rädecker et al., 2014; Cardini et al., 2015; Pogoreutz et al., 2017). Similarly, an absence of detectable nitrogen fixation was previously reported for the fungiid coral Fungia fungites (Shashar et al., 1994). Our present study shows that physiological differences in holobiont nitrogen fixation rates align with relative nifH gene abundance and activity, and hence, likely reflect differences of nitrogen-fixing bacteria in the tissues of these corals, highlighting molecular differences on the coral family level.

To understand the distinct physiological and molecular patterns in diazotrophy, the ecological context of the investigated coral families, particularly the trophic functional groups, must be considered. The observed patterns in diazotrophy align with differential heterotrophic feeding capacities of the investigated coral holobionts. While Fungiidae are highly heterotrophic and can exploit a large variety of food sources (Houlbrèque and Ferrier-Pagès, 2009), shallow-water Pocilloporidae have a very limited heterotrophic capacity and strongly rely on photoautotrophy (Muscatine et al., 1984; Muscatine and Kaplan, 1994; Ziegler et al., 2014). Given that the investigated functional groups align with family association, it remains to be determined whether the observed differences are reflecting ecological differences in autotrophic and heterotrophic corals at large, e.g., by the incorporation of further species. In any case, photosynthetically fixed carbon (photosynthate) is characterized by high C:N ratios compared to heterotrophic food sources (Falkowski et al., 1984; Muscatine et al., 1984). Therefore, high carbon availability coupled with strong nitrogen limitation in mostly autotrophic coral holobionts may select for relatively larger diazotroph populations compared to mostly heterotrophic coral holobionts. These results suggest that the importance of microbial nitrogen fixation depends on the heterotrophic capacity of the coral holobiont. This view is supported by previous studies showing differential partitioning of $\delta^{15} \mathrm{~N}$ in corals along a water depth gradient, indicating a higher importance of nitrogen fixation products in low-light adapted phototrophs compared to heterotrophs (Muscatine and Kaplan, 1994; Bednarz et al., 2017).

The observed physiological and molecular patterns in nitrogen fixation have important implications for our understanding of holobiont nutrient cycling and functioning. For instance, changes in nutrient cycling and stoichiometry can be involved in coral symbiotic breakdown as recently shown (Wiedenmann et al., 2012; Ezzat et al., 2016; Pogoreutz et al., 2017). Indeed, while the input of 'new' nitrogen from diazotrophy may be beneficial for holobiont functioning in oligotrophic reef waters (Cardini et al., 2015; Benavides et al., 2016), stimulated nitrogen fixation activity may be linked to detrimental effects on Symbiodinium photophysiology and coral bleaching (Santos et al., 2014; Rädecker et al., 2015; Pogoreutz et al., 2017). Hence, diazotrophs may be considered beneficial microorganisms for corals (BMCs) under stable, oligotrophic conditions (Peixoto et al., 2017). Yet, their presence may affect the corals' susceptibility to stress during environmental change highlighting the importance of understanding the role of microbes in holobiont functioning and breakdown (Sweet and Bulling, 2017). Indeed, Pocilloporidae are highly sensitive to thermal stress (McClanahan, 2004; Pinzón et al., 2013; Swain et al., 2016), whereas Fungiidae are resistant to a range of environmental stressors (Chadwick and Loya, 1990; Hoeksema, 1991; Philipp and Fabricius, 2003; Baria et al., 2015; Röthig et al., 2016; Swain et al., 2016). We thus argue that a strong coral host dependency on microbial nitrogen fixation may render corals more vulnerable to the effects of environmental change. Hence, future research efforts should be directed to disentangle a potential link between coral-associated nitrogen fixation and holobiont stress susceptibility. Understanding this link will assist to improve current reef conservation measures.

Taken together, our study provides insight into the ecological underpinnings that may underlie differences in diazotrophy of the coral holobiont with implications for coral host environmental resilience. As such, our work contributes to the growing body of literature that suggests the importance of microbes to metaorganism function. Future work assessing the diversity and composition of coral-associated diazotroph communities in a comparative coral taxonomic framework, e.g., via nifH gene sequencing (Lema et al., 2012; Santos et al., 2014) will provide additional insight into host-microbe interactions.

\section{AUTHOR CONTRIBUTIONS}

$\mathrm{CP}, \mathrm{NR}, \mathrm{CW}$, and CV conceived and designed the experiment. $\mathrm{CP}$ and NR conducted the experiments, analyzed, and interpreted the data. AC, CW, and CV contributed reagents and tools. $\mathrm{CP}, \mathrm{NR}, \mathrm{CW}$, and $\mathrm{CV}$ drafted and all authors revised the article. All authors have agreed to and approved the final article.

\section{FUNDING}

CP was supported by GLOMAR - Bremen International Graduate School for Marine Sciences. NR was supported by the DAAD Promos Scholarship. CV acknowledges funding by the King Abdullah University of Science and Technology (KAUST). This work was also supported by German Research Foundation (DFG) grant Wi 2677/9-1 to $\mathrm{CW}$.

\section{ACKNOWLEDGMENTS}

The authors thank A.M. Al-Suwailem and Z. Batang for allocation of workspace and P. Muller for technical support at the Core Lab for Coastal and Marine Resources (KAUST).We thank R. Aljadahli, H. Aljadahli, and D. Pallett for support with marine operations, T. Röthig and M. Ziegler for assistance 
with coral collection, B. Hoeksema for taxonomic clarifications, and Zeyad al-Tallah and N. Karbathia for support with ethylene measurements. Further, the authors would like to thank the editor as well as the two reviewers for their constructive feedback on the manuscript.

\section{REFERENCES}

Alamaru, A., Bronstein, O., Dishon, G., and Loya, Y. (2009). Opportunistic feeding by the fungiid coral Fungia scruposa on the moon jellyfish Aurelia aurita. Coral Reefs 28, 865-865. doi: 10.1007/s00338-009-0507-7

Aranda, M., Li, Y., Liew, Y. J., Baumgarten, S., Simakov, O., Wilson, M. C., et al. (2016). Genomes of coral dinoflagellate symbionts highlight evolutionary adaptations conducive to a symbiotic lifestyle. Sci. Rep. 6:39734. doi: 10.1038/ srep39734

Arif, C., Daniels, C., Bayer, T., Banguera-Hinestroza, E., Barbrook, A., Howe, C. J., et al. (2014). Assessing Symbiodinium diversity in scleractinian corals via nextgeneration sequencing-based genotyping of the ITS2 rDNA region. Mol. Ecol. 23, 4418-4433. doi: 10.1111/mec.12869

Baria, M. V. B., Kurihara, H., and Harii, S. (2015). Tolerance to elevated temperature and ocean acidification of the larvae of the solitary corals Fungia fungites (Linnaues, 1758) and Lithophyllon repanda (Dana, 1846). Zoolog. Sci. 32, 447-454. doi: 10.2108/zs150036

Bayer, T., Neave, M. J., Alsheikh-Hussain, A., Aranda, M., Yum, L. K., Mincer, T., et al. (2013). The microbiome of the red sea coral Stylophora pistillata is dominated by tissue-associated Endozoicomonas bacteria. Appl. Environ. Microbiol. 79, 4759-4762. doi: 10.1128/AEM.00695-13

Bednarz, V. N., Grover, R., Maguer, J.-F., Fine, M., and Ferrier-Pagès, C. (2017). The assimilation of diazotroph-derived nitrogen by scleractinian corals depends on their metabolic status. mBio 8:e02058-16. doi: 10.1128/mBio.02058-16

Benavides, M., Houlbrèque, F., Camps, M., Lorrain, A., Grosso, O., and Bonnet, S. (2016). Diazotrophs: a non-negligible source of nitrogen for the tropical coral Stylophora pistillata. J. Exp. Biol. 219, 2608-2612. doi: 10.1242/jeb.139451

Cardini, U., Bednarz, V. N., Naumann, M. S., van Hoytema, N., Rix, L., Foster, R. A., et al. (2015). Functional significance of dinitrogen fixation in sustaining coral productivity under oligotrophic conditions. Proc. R. Soc. B Biol. Sci. 282, 20152257. doi: 10.1098/rspb.2015.2257

Chadwick, N. E., and Loya, Y. (1990). Regeneration after experimental breakage in the solitary reef coral Fungia granulosa Klunzinger, 1879. J. Exp. Mar. Biol. Ecol. 142, 221-234. doi: 10.1016/0022-0981(90)90093-R

Ezzat, L., Maguer, J.-F., Grover, R., Ferrier-Pagès, C., Six, D. L., Doney, S. C., et al. (2016). Limited phosphorus availability is the achilles heel of tropical reef corals in a warming ocean. Sci. Rep. 6:31768. doi: 10.1038/srep31768

Falkowski, P. G., Dubinsky, Z., Muscatine, L., and Mccloskey, L. (1993). Population control in symbiotic corals. Bioscience 43, 606-611. doi: 10.1371/journal.pone. 0139223

Falkowski, P. G., Dubinsky, Z., Muscatine, L., and Porter, J. W. (1984). Light and bioenergetics of a symbiotic coral. Bioscience 34, 705-709. doi: 10.2307/1309663

Gaby, J. C., and Buckley, D. H. (2012). A comprehensive evaluation of PCR primers to amplify the nifH gene of nitrogenase. PLOS ONE 7:e42149. doi: 10.1371/ journal.pone.0042149

Hardy, R. W., Holsten, R. D., Jackson, E. K., and Burns, R. C. (1968). The acetylene - ethylene assay for N2 fixation: laboratory and field evaluation. Plant Physiol. 43, 1185-1207. doi: 10.1104/pp.43.8.1185

Hoeksema, B. W. (1991). Control of bleaching in mushroom coral populations (Scleractinia: Fungiidae) in the Java Sea: stress tolerance and interference by life history strategy. Mar. Ecol. Prog. Ser. 74, 225-237. doi: 10.3354/meps075225

Hoeksema, B. W., and Waheed, Z. (2012). It pays to have a big mouth: Mushroom corals ingesting salps at northwest Borneo. Mar. Biodivers. 42, 297-302. doi: 10.1007/s12526-012-0110-y

Houlbrèque, F., and Ferrier-Pagès, C. (2009). Heterotrophy in tropical scleractinian corals. Biol. Rev. Camb. Philos. Soc. 84, 1-17. doi: 10.1111/j.1469-185X.2008. 00058.x

LaJeunesse, T. C. (2002). Diversity and community structure of symbiotic dinoflagellates from Caribbean coral reefs. Mar. Biol. 141, 387-400. doi: 10.1007/s00227-002-0829-2

\section{SUPPLEMENTARY MATERIAL}

The Supplementary Material for this article can be found online at: http://journal.frontiersin.org/article/10.3389/fmicb. 2017.01187/full\#supplementary-material

Lema, K. A., Bourne, D. G., and Willis, B. L. (2014). Onset and establishment of diazotrophs and other bacterial associates in the early life history stages of the coral Acropora millepora. Mol. Ecol. 23, 4682-4695. doi: 10.1111/mec.12899

Lema, K. A., Willis, B. L., and Bourne, D. G. (2012). Corals form characteristic associations with symbiotic nitrogen-fixing bacteria. Appl. Environ. Microbiol. 78, 3136-3144. doi: 10.1128/AEM.07800-11

Lesser, M. P., Falcón, L. I., Rodríguez-román, A., Enríquez, S., Hoegh-guldberg, O., and Iglesias-prieto, R. (2007). Nitrogen fixation by symbiotic cyanobacteria provides a source of nitrogen for the scleractinian coral Montastraea cavernosa. Mar. Ecol. Prog. Ser. 346, 143-152. doi: 10.3354/meps07008

McClanahan, T. R. (2004). The relationship between bleaching and mortality of common corals. Mar. Biol. 144, 1239-1245. doi: 10.1007/s00227-003-1271-9

Mortenson, L. E. E. (1964). Ferredoxin and ATP, requirements for nitrogen fixation in cell-free extracts of Clostridium pasteurianum. Proc. Natl. Acad. Sci. U.S.A. 52, 272-279. doi: 10.1073/pnas.52.2.272

Muscatine, L. (1990). “The role of symbiotic algae in carbon and energy flux in reef corals," in Ecosystems of the World, Coral Reefs, ed. Z. Dubinsky (Amsterdam: Elsevier), 75-87.

Muscatine, L., Falkowski, P. G., Porter, J. W., and Dubinsky, Z. (1984). Fate of photosynthetic fixed carbon in light- and shade-adapted colonies of the symbiotic coral Stylophora pistillata. Proc. R. Soc. B 222, 181-202. doi: 10.1098/ rspb.1984.0058

Muscatine, L., Ferrier-Pagès, C., Blackburn, A., Gates, R. D., Baghdasarian, G., and Allemand, D. (1998). Cell-specific density of symbiotic dinoflagellates in tropical anthozoans. Coral Reefs 17, 329-337. doi: 10.1007/s003380050133

Muscatine, L., and Kaplan, I. R. (1994). Resource partitioning by reef corals as determined from stable isotope composition. Pacific Sci. 48, 304-312. doi: 10.1007/BF00391957

Peixoto, R. S., Rosado, P. M., de Assis Leite, D. C., Rosado, A. S., and Bourne, D. G. (2017). Beneficial microorganisms for corals (BMC): proposed mechanisms for coral health and resilience. Front. Microbiol. 8:341. doi: 10.3389/fmicb.2017. 00341

Philipp, E., and Fabricius, K. (2003). Photophysiological stress in scleractinian corals in response to short-term sedimentation. J. Exp. Mar. Biol. Ecol. 287, 57-78. doi: 10.1016/S0022-0981(02)00495-1

Pinzón, J. H., Sampayo, E., Cox, E., Chauka, L. J., Chen, C. A., Voolstra, C. R., et al. (2013). Blind to morphology: genetics identifies several widespread ecologically common species and few endemics among Indo-Pacific cauliflower corals (Pocillopora, Scleractinia). J. Biogeogr. 40, 1595-1608. doi: 10.1111/jbi. 12110

Pogoreutz, C., Rädecker, N., Cárdenas, A., Gärdes, A., Voolstra, C. R., and Wild, C. (2017). Sugar enrichment provides evidence for a role of nitrogen fixation in coral bleaching. Glob. Chang. Biol. doi: 10.1111/gcb.13695 [Epub ahead of print].

Rädecker, N., Meyer, F. W., Bednarz, V. N., Cardini, U., Wild, C., Carnini, U., et al. (2014). Ocean acidification rapidly decreases dinitrogen fixation associated with the hermatypic coral Seriatopora hystrix. Mar. Ecol. Prog. Ser. 511, 297-302. doi: 10.3354/meps10912

Rädecker, N., Pogoreutz, C., Voolstra, C. R., Wiedenmann, J., and Wild, C. (2015). Nitrogen cycling in corals: the key to understanding holobiont functioning? Trends Microbiol. 23, 490-497. doi: 10.1016/j.tim.2015.03.008

Rahav, O., Dubinsky, Z., Achituv, Y., and Falkowski, P. G. (1989). Ammonium metabolism in the zooxanthellate coral, Stylophora pistillata. Proc. R. Soc. B Biol. Sci. 236, 325-337. doi: 10.1098/rspb.1989.0026

Roder, C., Bayer, T., Aranda, M., Kruse, M., and Voolstra, C. R. (2015). Microbiome structure of the fungid coral Ctenactis echinata aligns with environmental differences. Mol. Ecol. 24, 3501-3511. doi: 10.1111/mec.13251

Rohwer, F., Seguritan, V., Azam, F., and Knowlton, N. (2002). Diversity and distribution of coral-associated bacteria. Mar. Ecol. Prog. Ser. 243, 1-10. doi: 10.3354/meps 243001 
Röthig, T., Ochsenkühn, M. A., Roik, A., van der Merwe, R., Voolstra, C. R., Roethig, T., et al. (2016). Long-term salinity tolerance is accompanied by major restructuring of the coral bacterial microbiome. Mol. Ecol. 25, 1308-1323. doi: $10.1111 / \mathrm{mec} .13567$

Santos, H. F., Carmo, F. L., Duarte, G., Dini-Andreote, F., Castro, C. B., Rosado, A. S., et al. (2014). Climate change affects key nitrogen-fixing bacterial populations on coral reefs. ISME J. 8, 2272-2279. doi: 10.1038/ismej. 2014.70

Sawall, Y., Al-Sofyani, A., Hohn, S., Banguera-Hinestroza, E., Voolstra, C. R., and Wahl, M. (2015). Extensive phenotypic plasticity of a Red Sea coral over a strong latitudinal temperature gradient suggests limited acclimatization potential to warming. Sci. Rep. 5:8940. doi: 10.1038/srep08940

Shashar, N., Cohen, Y., Loya, Y., and Sar, N. (1994). Nitrogen fixation (acetylene reduction) in stony corals - Evidence for coral-bacteria interactions. Mar. Ecol. Prog. Ser. 111, 259-264. doi: 10.3354/meps111259

Swain, T. D., Vega-Perkins, J. B., Oestreich, W. K., Triebold, C., DuBois, E., Henss, J., et al. (2016). Coral bleaching response index: a new tool to standardize and compare susceptibility to thermal bleaching. Glob. Chang. Biol. 22, 2475-2488. doi: 10.1111/gcb.13276

Sweet, M. J., and Bulling, M. T. (2017). On the importance of the microbiome and pathobiome in coral health and disease. Front. Mar. Sci. 4:9. doi: 10.3389/fmars. 2017.00009
Wiedenmann, J., D’Angelo, C., Smith, E. G., Hunt, A. N., Legiret, F.-E., Postle, A. D., et al. (2012). Nutrient enrichment can increase the susceptibility of reef corals to bleaching. Nat. Clim. Change 2, 1-5. doi: 10.1038/nclimate1661

Wilson, S. T. T., Böttjer, D., Church, M. J. J., Karl, D. M. M., Bottjer, D., Church, M. J. J., et al. (2012). Comparative assessment of nitrogen fixation methodologies, conducted in the oligotrophic North Pacific Ocean. Appl. Environ. Microbiol. 78, 6516-6523. doi: 10.1128/AEM.01146-12

Ziegler, M., Roder, C. M., Büchel, C., and Voolstra, C. R. (2014). Limits to physiological plasticity of the coral Pocillopora verrucosa from the central Red Sea. Coral Reefs 33, 1115-1129. doi: 10.1007/s00338-014-1192-8

Conflict of Interest Statement: The authors declare that the research was conducted in the absence of any commercial or financial relationships that could be construed as a potential conflict of interest.

Copyright (c) 2017 Pogoreutz, Rädecker, Cárdenas, Gärdes, Wild and Voolstra. This is an open-access article distributed under the terms of the Creative Commons Attribution License (CC BY). The use, distribution or reproduction in other forums is permitted, provided the original author(s) or licensor are credited and that the original publication in this journal is cited, in accordance with accepted academic practice. No use, distribution or reproduction is permitted which does not comply with these terms. 